Tammi R. Duncan, Margaret Werner-Washburne, and Diana E. Northup. Diversity of siderophore-producing bacterial cultures from Carlsbad Caverns National Park caves, Carlsbad, New Mexico. Journal of Cave and Karst Studies, v. 83, no. 1, p. 29-43. DOI:10.4311/2019ES0118

\title{
DIVERSITY OF SIDEROPHORE-PRODUCING BACTERIAL CULTURES FROM CARLSBAD CAVERNS NATIONAL PARK CAVES, CARLSBAD, NEW MEXICO
}

\author{
Tammi R. Duncan ${ }^{1, C}$, Margaret Werner-Washburne ${ }^{2}$, and Diana E. Northup ${ }^{2}$
}

\begin{abstract}
Siderophores are microbially-produced ferric iron chelators. They are essential for microbial survival, but their presence and function for cave microorganisms have not been extensively studied. Siderophores are classified based on the common functional groups (catechols, hydroxamates, carboxylates, and mixed) that coordinate to ferric $\left(\mathrm{Fe}^{3+}\right)$ iron. Cave environments are nutrient-limited and previous evidence suggests siderophore usage in carbonate caves. We hypothesize that siderophores are likely used as a mechanism in caves to obtain critical ferric iron. Cave bacteria were collected from long-term parent cultures (LT PC) or short-term parent cultures (ST PC) inoculated with ferromanganese deposits (FMD) and carbonate secondary minerals from Lechuguilla and Spider caves in Carlsbad Caverns National Park, NM. LT PC were incubated for 10-11 years to identify potential chemolithoheterotrophic cultures able to survive in nutrient-limited conditions. ST PC were incubated for 1-3 days to identify a broader diversity of cave isolates. A total of 170 LT and ST cultures, 18 pure and 152 mixed, were collected and used to classify siderophore production and type and to identify siderophore producers. Siderophore production was slow to develop ( $>10$ days) in LT cultures with a greater number of weak siderophore producers in comparison to the ST cultures that produced siderophores in $<10$ days, with a majority of strong siderophore producers. Overall, $64 \%$ of the total cultures were siderophore producers, with the majority producing hydroxamate siderophores. Siderophore producers were classified into Proteobacteria (Alpha-, Beta-, or Gamma-), Actinobacteria, Bacteroidetes, and Firmicutes phyla using 16S rRNA gene sequencing. Our study supports our hypothesis that cave bacteria have the capability to produce siderophores in the subsurface to obtain critical ferric iron.
\end{abstract}

\section{INTRODUCTION}

The semi-arid caves in the Guadalupe Mountains, considered to be extreme environments for life, are excellent examples of aphotic and oligotrophic (low nutrients) carbonate cave systems (Northup and Lavoie, 2001). Despite resource limitations due to oligotrophic conditions, biodiversity is rich in the bacterial and archaeal domains and the fungal kingdom in cave environments (Tomczyk-Żak and Zielenkiewicz, 2016). Along with adapting to oligotrophic conditions, microorganisms in carbonate cave systems need mechanisms to acquire essential soluble ferrous iron. Ferric $\left(\mathrm{Fe}^{3+}\right)$ iron is more available then ferrous $\left(\mathrm{Fe}^{2+}\right)$ iron in Carlsbad Caverns National Park (CCNP) caves and can be hundreds to thousands of times more available in enriched FMDs in comparison to underlying bedrock (Northup et al., 2003; Spilde et al., 2005). Microorganisms deal with the limited availability of soluble ferrous $\left(\mathrm{Fe}^{2+}\right)$ iron by producing siderophores that break down insoluble ferric oxide-containing compounds to acquire essential soluble ferrous iron.

Siderophores are a unique class of small molecules that chelate and provide access to insoluble ferric $\left(\mathrm{Fe}^{3+}\right)$ iron with high binding affinity from their environments (Dave et al., 2006; Chu et al., 2010; Hider and Kong, 2010; Ahmed and Holmström, 2014). Siderophores are classified based on the common functional groups (catechols, hydroxamates, carboxylates, and mixed) that coordinate to ferric ( $\mathrm{Fe}^{3+}$ ) iron (Sandy and Butler, 2009; Khan et al., 2018). Bacteria, archaea, and fungi produce and excrete siderophores in response to low intracellular iron levels (Dave et al., 2006; Chu et al., 2010; Ahmed and Holmström, 2014). Siderophores secreted into the environment can be used either by individual bacteria and fungi, or shared and competed for by multiple organisms in a community (i.e., microbial consortia) (Glick, 2003; Chu et al., 2010; Hider and Kong, 2010; Ahmed and Holmström, 2014). Because siderophores are valuable in acquiring and processing insoluble ferric $\left(\mathrm{Fe}^{3+}\right)$ iron, individual or mixed culture microorganisms are predicted to use siderophores in an oligotrophic environment.

Siderophore production by isolated bacteria has been shown in several low nutrient oligotrophic $(<2 \mathrm{mg} / \mathrm{L}$ total organic carbon (Barton and Jurado, 2007)) environments, such as the open ocean (Mawji et al., 2008; Boiteau et al., 2016; Velasquez et al., 2016; Bundy et al., 2018), cloud water (Vinatier et al., 2016), oligotrophic lakes (Sorichetti et al., 2014), cold deserts (Yadav et al., 2015), and recently, in a few carbonate caves (Hershey et al., 2014; Venkadesaperumal et al., 2014; Qin et al., 2017). Siderophores were shown to be produced by Pseudochrobactrum kiredjianiae strain A4 that was isolated from Karaulnaya-2 Cave, Russia (Qin et al., 2017) and by seven isolates collected from Mud Volcano

\footnotetext{
${ }^{1}$ Science \& Wellness Division, University of New Mexico-Valencia, 280 La Entrada Road, Los Lunas, New Mexico, 87031

${ }^{2}$ Department of Biology, MSC03-2020, 1 University of New Mexico, Albuquerque, NM, 87131

cCorresponding author: tammid31@unm.edu
} 
and Lime Cave, Baratang Island, India (Venkadesaperumal et al., 2014). Siderophore production was also detected from Lechuguilla Cave bacterial isolates in New Mexico (Hershey et al., 2014). The relative lack of information about isolates or mixed culture microorganisms that produce and use siderophores in oligotrophic caves, therefore, provides a rich area for discovery.

Caves in semi-arid areas have no phototrophy and any products of phototrophy are limited to what can filter down from surface soils. For example, drip water (seepage water) from within Lechuguilla Cave has shown that a limited amount of organic carbon is entering through this infiltration (Levy, 2007). In addition, Lechuguilla and Spider Caves, two semi-arid oligotrophic caves in CCNP, NM, also provide a variety of excellent microbial habitats, including wet carbonate secondary mineral deposit surfaces (Hill and Forti, 1997) and ferromanganese deposits (FMDs) (Northup et al., 2000; Spilde et al., 2005). FMDs, classified by color, were documented to have high iron oxide levels in red orange/red brown (8.18-30.30 wt \%), chocolate brown (17.07-23.79 wt \%), and black (10.66-17.07 wt \%) FMDs relative to bedrock (0.01-0.03 wt \%) (Northup et al., 2003; Spilde et al., 2005). FMDs with documented high ferric iron levels relevant to bedrock could be good sources of ferric iron that would require the use of siderophores by microorganisms in these microenvironments.

We hypothesized that cave bacteria would possess the ability to produce siderophores to acquire ferric iron to process for critical ferrous iron needed for cellular processes. Supporting our hypothesis, we found that siderophores were produced by cultured bacteria from cave deposits in Lechuguilla and Spider Caves. To our knowledge, this siderophore study is also the first to identify cave mixed bacterial cultures that have the ability to produce siderophores.

\section{MATERIALS AND METHODS}

\section{Cave Site Description and Sampling}

We sampled from two caves, Spider Cave and Lechuguilla Cave, CCNP (Fig. 1A). Spider and Lechuguilla Caves have relatively stable air temperatures of $17.0-18.4{ }^{\circ} \mathrm{C}$ (Spider) and $\sim 19-20{ }^{\circ} \mathrm{C}$ (Lechuguilla), and a relative humidity of $99-100 \%$ once you reach the deep cave zone (Northup et al., 2003). Both caves are oligotrophic. Brusseau et al. (2019) characterizes the unsaturated subsurface vadose zone as having a very low organic carbon content, usually less than $0.1 \%$, or $<2 \mathrm{mg} / \mathrm{L}$ total organic carbon (Barton and Jurado, 2007). Spider Cave has $<0.104 \%$ organic carbon in the deposits that have the most biodiversity (i.e., Ferromanganese deposits) and punk rock (Northup et al 2003). Several pool water samples from Lechuguilla had dissolved organic carbon measurements of less than $1 \mathrm{mg} / \mathrm{L}$, except for one that was $1.7 \mathrm{mg} / \mathrm{L}$ (Levy 2007).

Both caves are formed in the Permian Reef Complex, a moderately dissected, gently tilted plateau of reef to backreef strata above the Guadalupe Escarpment (Hayes, 1964; Palmer and Palmer, 2009). Spider Cave is located within dolomite bedded back-reef strata, has $9.8 \mathrm{~km}$ of mapped passage, and a maximum depth below the surface of 42.4 $\mathrm{m}$ (Gulden, 2019). Lechuguilla Cave, in contrast, is located in both the calcite to dolomite massive reef and bedded back-reef strata, has $222.6 \mathrm{~km}$ of mapped passage, and a maximum depth below the surface of $489 \mathrm{~m}$ (Gulden, 2019).

\section{Isolation of LT Par- ent Cultures}

LT cultures were utilized as a major part of our siderophore research because long-term survival of microorganisms on low nutrients is an adaptation by microorganisms to oligotrophic environments, such as found in our caves. We hypothesized that the LT cultures would have selected for actively-growing cave bacteria capable of showing long-term
A

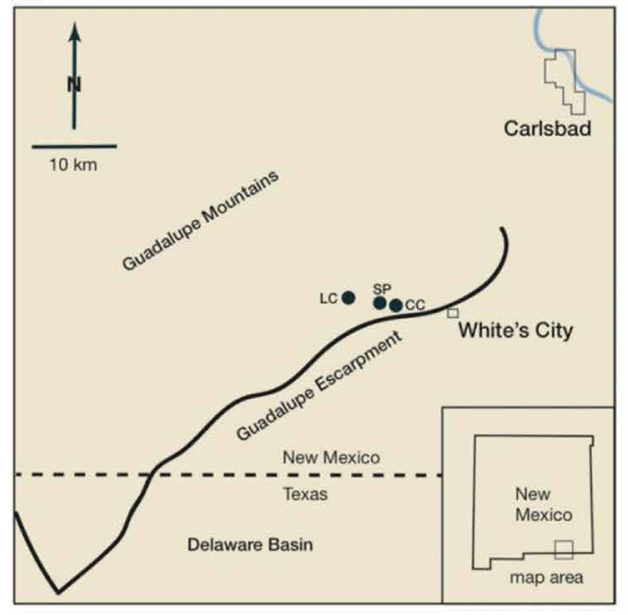

B

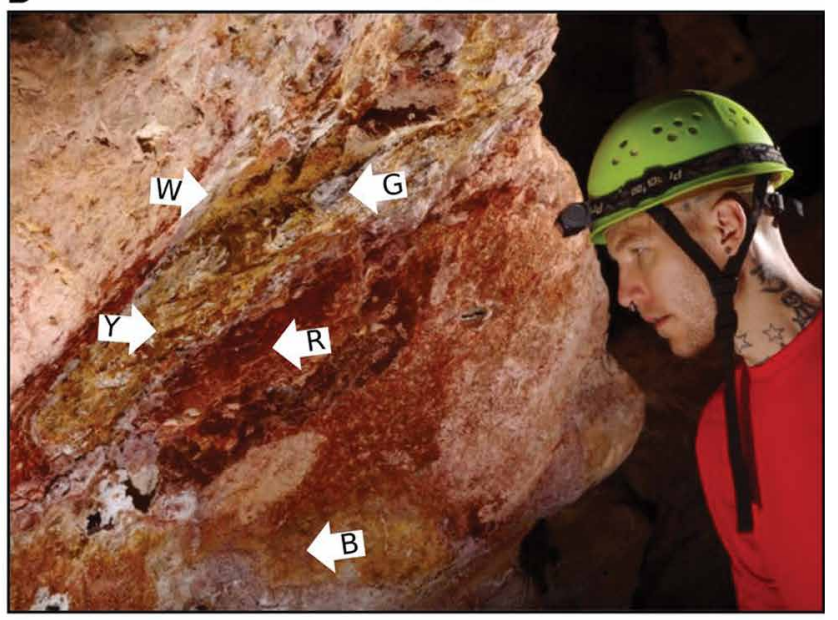

Figure1. (A) General map area of the Carlsbad Caverns National Park (CCNP) near the New Mexico and Texas border (dashed lines). Approximate locations of Lechuguilla Cave (LC), Spider Cave (SC), and nearby Carlsbad Cavern (CC) along the Guadalupe Escarpment (solid line) south east of Carlsbad, NM. Map was released under the Attribution 4.0 International (CC-BY 4.0) license. Redrafted by A. Winter from the original in (Hayes, 1964). (B) Representative in-cave sample site of varying colors of ferromanganese deposits (FMD) and punk rock: W-white punk rock, brown FMD-B, grey FMD-G, red FMD-R, and yellow FMD-Y. Photo by Kenneth Ingham. 
survival in media with inorganic and minimal organic energy sources. Therefore, LT cultures would likely be cultures of chemolithoheterotrophic bacteria able to utilize inorganic chemicals for their energy and rely on organic chemicals for their carbon sources and possibly energy from the cave walls and secondary deposits. LT parent cultures, LT PC-1 to LT PC-4, were inoculated with yellow FMD (Spider Cave), brown and orange FMD (Lechuguilla Cave), and punk rock (Lechuguilla Cave) (Table 1). Punk rock is a zone of soft altered bedrock (Hill, 1987). The representative colors of ferromanganese deposits are shown in Figure 1B.

Table 1. Long-term (LT) parent cultures, sample location and type, and total subcultured bacterial cultures ( $n=80)$.

\begin{tabular}{|c|c|c|c|c|c|c|c|c|}
\hline \multirow{2}{*}{$\begin{array}{c}\text { Parent } \\
\text { Culture No. }\end{array}$} & \multirow{2}{*}{$\begin{array}{l}\text { Parent } \\
\text { Cultures }\end{array}$} & \multirow[b]{2}{*}{ Parent Media } & \multirow[b]{2}{*}{ Cave } & \multirow{2}{*}{$\begin{array}{c}\text { Parent } \\
\text { Sample type }\end{array}$} & \multicolumn{3}{|c|}{$\begin{array}{l}\text { No. of cultures } \\
\text { collected } \\
\text { from subculture }\end{array}$} & \multirow[b]{2}{*}{ Total } \\
\hline & & & & & $\mathbf{R} \mathrm{A}^{\mathrm{a}}$ & $\mathrm{R}^{2} \mathrm{~A}^{\mathrm{b}}$ & $A \mid A^{a, b}$ & \\
\hline LT PC-1 & 011505-14 & Reduced Mn-supplement & Spider & Yellow FMD & 21 & 14 & 5 & 40 \\
\hline LT PC-2 & $\mathrm{Fe}+\mathrm{C}^{1} 011101-72$ & Reduced Fe-supplement & Lechuguilla $^{c}$ & Brown and Orange FMD & 5 & 8 & 0 & 13 \\
\hline LT PC-3 & $M n+P_{0} 011101-63$ & Reduced Mn-supplement & Lechuguilla ${ }^{c}$ & Punk Rock & 6 & 6 & 2 & 14 \\
\hline LT PC-4 & $\mathrm{Mn}-\mathrm{C}_{0} 011101-48$ & Reduced Mn-supplement & Lechuguilla $^{c}$ & Brown and Orange FMD & 4 & 6 & 3 & 13 \\
\hline
\end{tabular}

To collect cave deposits for inoculation of potential chemolithoheterotrophic LT parent cultures, sterile loops were used to collect cave samples that were stabbed into parent screw-cap test tubes (16mm diameter, $100 \mathrm{~mm}$ length) filled with sterile basal medium and taken to the lab in the dark. Test tube agars all consisted of the following basal medium (per liter): $0.5 \mathrm{~g} \mathrm{NaCl}, 0.5 \mathrm{~g} \mathrm{CaCO}_{3}, 0.5 \mathrm{~g} \mathrm{MgSO}_{4} \cdot 7 \mathrm{H}_{2} \mathrm{O}, 0.75 \mathrm{~g} \mathrm{~K}_{2} \mathrm{HPO}_{4}, 0.25 \mathrm{~g} \mathrm{NaH}_{2} \mathrm{PO}_{4}, 0.1 \mathrm{~g} \mathrm{KNO}, 4 \mathrm{~g}$ Bacto agar (contains linear polysaccharide agarose and heterogenous agaropectin), and sterile Milli-Q $\mathrm{H}_{2} \mathrm{O}$. This basal medium was enriched with reduced manganese (Mn) for LT PC-1, LT PC-3, and LT PC-4, and enriched with reduced iron (Fe) for LT PC-2 (Table 1) to represent cave conditions and as a possible energy source. For $\mathrm{Mn}$ supplements, $0.02 \mathrm{~g} / \mathrm{L}$ of $\mathrm{MnCl}_{2}$ was added and for iron supplements, one sterile reduced iron carpet tack was added to the bottom of the test tube.

To promote the selection of potential chemolithoheterotrophic cave bacterial cultures capable of LT survival in media with inorganic energy sources, LT parent cultures were incubated for years in the cave, lab, or both. Additional in-cave incubation parameters were tested using were lightly sealed test tubes placed in a container on the ground in an area remote from the travel trails in the dark zone. The Spider Cave LT PC-1 was incubated in the cave for six years and subsequently transferred to a lab incubator and incubated for five additional years $\left(20^{\circ} \mathrm{C}\right.$, dark, and no added humidity) (Table S1). Lechuguilla Cave LT PC-2 to LT PC-4 were incubated in the cave for one to three days, transferred to lab incubator $\left(20^{\circ} \mathrm{C}\right.$, dark, and no added humidity), and incubated for 10 years (Table S1).

\section{Subculture of LT Bacterial Cultures}

Eighty cultures collected from LT parent cultures are shown in Table 1. LT bacterial cultures were subcultured from LT PC-1 to LT PC-4 by collection at three depths from each LT parent culture using a sterile loop and aseptically streaked onto three isolation media that contained carbon: $\mathrm{R} 2 \mathrm{~A}+\mathrm{FeCl}_{3}, \mathrm{R} 2 \mathrm{~A}+\mathrm{MnCO}_{3}$, and $\mathrm{AIA}+\mathrm{FeCl}_{3}+\mathrm{MnCO}_{3}$ agar plates targeting potential chemolithoheterotrophs and heterotrophs. The Reasoner's 2A agar medium (R2A, Difco, Sparks, Md.) and Actinomycetes Isolation Agar (AIA, Difco, Sparks, Md.) were made according to manufacturer's instructions. For added supplements, $0.01 \mathrm{FeCl}_{3} \mathrm{~g} / \mathrm{L}$ and $0.1 \mathrm{MnCO}_{3} \mathrm{~g} / \mathrm{L}$ were added to the media and autoclaved. The inoculated agar plates were incubated at $20^{\circ} \mathrm{C}$ (no added humidity and in the dark) and individual bacterial colonies were collected upon first appearance four to 25 days (Table S1). The bacterial colonies were streaked once again for individual colonies and $20 \%$ glycerol stocks were prepared with R2B Medium (R2B, Millipore Sigma, Burlington, Mass., same as R2A with no agar) for long-term preservation at $-80^{\circ} \mathrm{C}$.

\section{Isolation of ST Parent Cultures}

Five different media types were utilized with ST cultures to cultivate a broader diversity of cave bacterial cultures with chemoheterotrophic metabolic capabilities to complement LT cultures. ST PC-5 to ST PC-44 were inoculated with FMD (gray, brown, red, yellow), carbonate speleothem, and wet carbonate cave deposits collected from Lechuguilla Cave (Table 2).

To collect cave deposits for inoculation of ST parent cultures, a sterile BD polyester fiber tipped application swab (Falcon) moistened with sterile Ringer's solution pH 7.3-7.4 (Inglis, 2008) was used to collect cave deposits followed by 
Table 2. Short-term (ST) parent cultures from Lechuguilla Cave, sample location and type, and total subcultured bacterial cultures $(n=90)$.

\begin{tabular}{|c|c|c|c|c|c|}
\hline Location & Parent Culture No. & $\begin{array}{c}\text { Parent } \\
\text { Cultures }\end{array}$ & Parent Sample Type & Parent Media & $\begin{array}{l}\text { Total No. } \\
\text { Cultures }\end{array}$ \\
\hline \multirow[t]{10}{*}{ EA Junction } & ST PC-5 & L120303-2a & Grey FMD & $1 / 2 R 2 A+$ rock flour & 3 \\
\hline & ST PC-6 & L120303-3a & Grey FMD & BG11 & 3 \\
\hline & ST PC-7 & L120303-5a & Grey FMD & AIA & 3 \\
\hline & ST PC-8 & L120303-6a & Brown FMD & $1 / 2 \mathrm{R} 2 \mathrm{~A}$ & 3 \\
\hline & ST PC-9 & L120303-10a & Brown FMD & AIA & 3 \\
\hline & ST PC-10 & L120303-12a & Carbonate speleothem & $1 / 2$ R2A + rock flour & 3 \\
\hline & ST PC-11 & L120303-14 ${ }^{a}$ & Carbonate speleothem & AlA + nystatin & 3 \\
\hline & ST PC-12 & L120303-17a & Yellow FMD & $1 / 2$ R2A + rock flour & 3 \\
\hline & ST PC-13 & L120303-18a & Yellow FMD & BG11 & 3 \\
\hline & ST PC-14 & L120303-20a & Yellow FMD & AIA & 3 \\
\hline \multirow[t]{10}{*}{ Lake Chandelar } & ST PC-15 & L120303-21 & Wet Carbonate & $1 / 2 \mathrm{R} 2 \mathrm{~A}$ & 2 \\
\hline & ST PC-16 & L120303-22 & Wet Carbonate & $1 / 2$ R2A + rock flour & 2 \\
\hline & ST PC-17 & L120303-28 & Wet Carbonate & BG11 & 2 \\
\hline & ST PC-18 & L120303-30 & Wet Carbonate & AIA & 2 \\
\hline & ST PC-19 & L120303-32 & Wet Carbonate & $1 / 2 R 2 A+$ rock flour & 2 \\
\hline & ST PC-20 & L120303-35 & Wet Carbonate & AIA & 2 \\
\hline & ST PC-21 & L120303-36 & Carbonate speleothem ${ }^{a}$ & $1 / 2 \mathrm{R} 2 \mathrm{~A}$ & 2 \\
\hline & ST PC-22 & L120303-37 & Carbonate speleothem ${ }^{a}$ & $1 / 2 R 2 A+$ rock flour & 2 \\
\hline & ST PC-23 & L120303-38 & Carbonate speleothem ${ }^{a}$ & BG11 & 2 \\
\hline & ST PC-24 & L120303-40 & Carbonate speleothem ${ }^{a}$ & $\mathrm{AlA}$ & 2 \\
\hline \multirow[t]{10}{*}{ Tower Place } & ST PC-25 & L120304-41 & Wet Carbonate & $1 / 2 \mathrm{R} 2 \mathrm{~A}$ & 2 \\
\hline & ST PC-26 & L120304-43 & Wet Carbonate & BG11 & 2 \\
\hline & ST PC-27 & L120304-47 & Wet Carbonate & $1 / 2 R 2 A+$ rock flour & 2 \\
\hline & ST PC-28 & L120304-48 & Wet Carbonate & BG11 & 2 \\
\hline & ST PC-29 & L120304-49 & Wet Carbonate & AlA + nystatin & 2 \\
\hline & ST PC-30 & L120304-52 & Red FMD & $1 / 2 R 2 A+$ rock flour & 2 \\
\hline & ST PC-31 & L120304-53 & Red FMD & BG11 & 2 \\
\hline & ST PC-32 & L120304-55 & Red FMD & AIA & 2 \\
\hline & ST PC-33 & L120304-57 & Wet Carbonate & $1 / 2 R 2 A+$ rock flour & 2 \\
\hline & ST PC-34 & L120304-58 & Wet Carbonate & BG11 & 2 \\
\hline \multirow[t]{10}{*}{ Briny Pool } & ST PC-35 & L120305-81 & Carbonate speleothem & $1 / 2 \mathrm{R} 2 \mathrm{~A}+$ rock flour & 2 \\
\hline & ST PC-36 & L120305-82 & Carbonate speleothem & BG11 & 2 \\
\hline & ST PC-37 & L120305-84 & Carbonate speleothem & AIA & 2 \\
\hline & ST PC-38 & L120305-85 & Carbonate speleothem & $1 / 2 \mathrm{R} 2 \mathrm{~A}$ & 2 \\
\hline & ST PC-39 & L120305-87 & Carbonate speleothem & BG11 & 2 \\
\hline & ST PC-40 & L120305-88 & Carbonate speleothem & AIA + nystatin & 2 \\
\hline & ST PC-41 & L120305-89 & Carbonate speleothem & AIA & 2 \\
\hline & ST PC-42 & L120305-91 & Carbonate speleothem & $1 / 2 \mathrm{R} 2 \mathrm{~A}+$ rock flour & 2 \\
\hline & ST PC-43 & L120305-94 & Carbonate speleothem & AIA & 2 \\
\hline & ST PC-44 & L120305-95 & Carbonate speleothem & $1 / 2 \mathrm{R} 2 \mathrm{~A}$ & 2 \\
\hline
\end{tabular}


streaking onto five types of sterile parent agar media (Table 2). Parent media types, all containing organic carbon, were made as follows (per liter): $1 / 2$ Reasoner's 2A medium (R2A), $1 / 2$ R2A with $5 \mathrm{~g}$ rock flour (Lower Guadalupe Mountains surface limestone that was pulverized in a rock crusher and autoclaved), BG11 (Atlas, 2004), Actinomycetes Isolation Agar (AIA), and AIA with nystatin $0.072 \mathrm{mg} / \mathrm{mL}$ (Sigma-Aldrich, St. Louis, Mo.). These media target oligotrophic (1/2 R2A), bacteria adapted to Guadalupe Mountains caves (rock flour), and Actinobacteria (AIA).

To enhance the growth of a broad diversity of cave bacterial cultures, ST PC- 5 to ST PC-44 were incubated in the cave for 1-3 days initially to give cave-adapted bacteria a head start under conditions to which they are adapted, followed by further growth time in the lab. Plates were incubated in the cave 1 to 3 days and transported in a cooler to a lab incubator $\left(20^{\circ} \mathrm{C}\right.$, dark, and no added humidity) for 23 days before subculturing (Table S1). Both pure (one organism) and mixed (2 or more organisms) cultures of siderophore producers were confirmed with sequencing.

\section{Subculture of ST Bacterial Cultures}

Ninety cultures were collected from ST parent cultures (Table 2). ST bacterial cultures were subcultured by collecting cells from ST parent cultures, ST PC- 5 to ST PC-44, using a sterile loop and aseptically streaking onto $1 / 2$ R 2 A agar plates, targeting oligotrophs. The inoculated $1 / 2$ R2A agar plates were incubated in the lab at $20^{\circ} \mathrm{C}$ (no added humidity and in the dark) and subsequent individual bacterial colonies were collected upon first appearance within a period of two to seven days (Table S1). The individual bacterial colonies were streaked once again for isolated colonies and 20 $\%$ glycerol stock were prepared with $1 / 2$ R2B Medium for long-term preservation at $-80^{\circ} \mathrm{C}$. Both pure (one organism) and mixed (two or more organisms) cultures of siderophore producers were confirmed with sequencing.

\section{Iron-limiting Growth of LT and ST Bacterial Cultures}

For iron-limiting growth conditions, a three-step process was completed. First, bacterial cultures were streaked from $20 \%$ glycerol freezer stocks onto sterile isolation subculture media and incubated at $20^{\circ} \mathrm{C}$ (no added humidity and in the dark) for four days (Table S1). Second, a heavy streak of the bacterial culture was transferred aseptically to modified ISP4 agar with Fe (Lee et al., 2012) and grown at $20^{\circ} \mathrm{C}$ (no added humidity and in the dark) for seven days. ISP4 medium was developed for detection of siderophores produced by soil Actinobacteria. Modified ISP4 agar plates with Fe contained (per liter): $4 \mathrm{~g} / \mathrm{L}$ soluble starch, $0.3 \mathrm{~g} / \mathrm{L}$ casein, $2 \mathrm{~g} / \mathrm{L} \mathrm{KNO}_{3}, 0.5 \mathrm{~g} / \mathrm{L} \mathrm{MgSO}{ }_{4} \cdot 7 \mathrm{H}_{2} \mathrm{O}, 0.02 \mathrm{~g} / \mathrm{L} \mathrm{CaCO}, 0.01$ $\mathrm{g} / \mathrm{L} \mathrm{FeSO}{ }_{4} \cdot 7 \mathrm{H}_{2} \mathrm{O}$ and $25 \mathrm{~g} / \mathrm{L}$ agar. Lastly, for subsequent Fe-depletion, the bacterial cultures were then transferred to iron-limiting ISP4 media that was modified by removal of $\mathrm{FeSO}_{4} \cdot 7 \mathrm{H}_{2} \mathrm{O}$ and casein and addition of $1 \mathrm{~g} / \mathrm{L}$ of yeast extract and incubated at $20^{\circ} \mathrm{C}$ (no added humidity and in the dark) for seven days (Table S1).

\section{Siderophore-induction of LT and ST Bacterial Cultures}

All cultures were screened with the Chrome Azurol S (CAS) assay then further tested for specific siderophores. Iron-limiting growth conditions were used to induce siderophore production and iron-starved bacterial cultures were plated on sterile CAS agar plates. CAS siderophore indicator plates were prepared as previously described (Schwyn and Neilands, 1987). Bacterial cultures were examined over time from the day of plating to the first day of halo. A CAS-color (blue) change to purple, described in the traditional CAS assay, indicated production of catechol-type siderophores. A CAS-color change to orange indicated hydroxamate siderophore production, while CAS-color change to completely clear probably indicated carboxylate siderophores (Pérez-Miranda et al., 2007; Sullivan et al., 2012). Negative siderophore production was monitored for approximately an additional month to verify no halo CAS-color change appearance surrounding the bacterial colonies. Representative phenotypes of CAS positive detection were categorized as siderophore-strong (>2mm zone of CAS-color change), -weak ( $<2 \mathrm{~mm}$ zone of CAS-color change), -none (no CAS-color change), or no growth of isolate (Fig. 2).

Arnow's and $\mathrm{FeCl}_{3}$ assays (Arnow, 1937; Neilands, 1981) were used to test for production of catecholate- and hydroxamate-type siderophores, respectively, according to protocols detailed in Lee et al., (2012). The bacterial cultures were exposed to iron-limiting conditions listed above and subsequently transferred to $2 \mathrm{~mL}$ of liquid ISP4 with no added iron for 53 days.
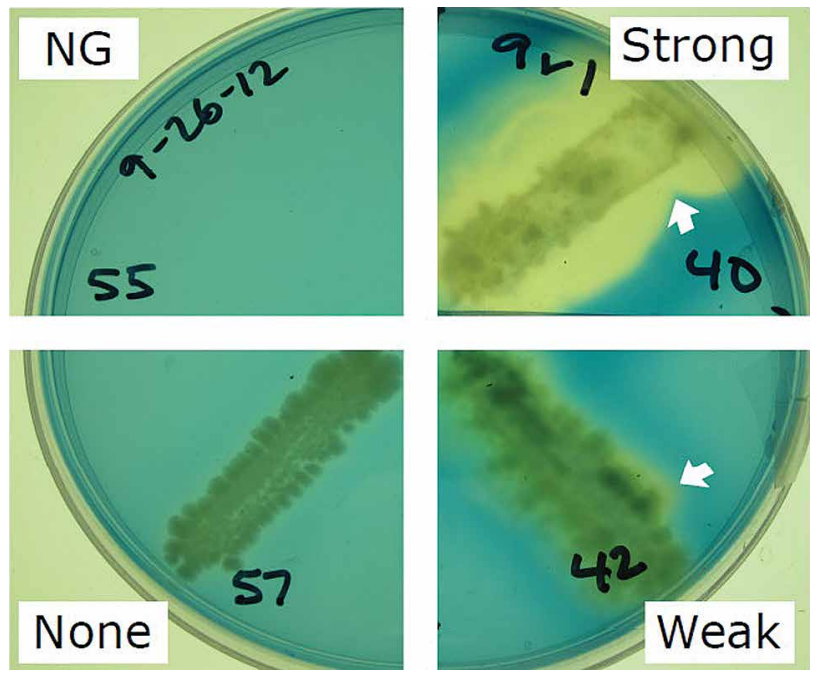

Figure 2. Chrome Azurol S (CAS) phenotypes showing varying production of siderophores by Fe-depleted cave cultures. Siderophore production is shown by the presence of color change around growth on CAS agar (arrows). Moving clockwise from top left: No growth (NG), Strong production $(>2 \mathrm{~mm})$, weak production $(<2 \mathrm{~mm})$, and no production (None). Numbers indicate cave culture identification number. 
Two $\mathrm{mL}$ of inoculated medium were centrifuged for $20 \mathrm{~min}$ at $13 \mathrm{~K} \mathrm{rpm}$ and the supernatant collected for Arnow's and $\mathrm{FeCl}_{3}$ assays. Catecholate $(6 \mu \mathrm{g} / \mathrm{mL})$ and hydroxamate, Desferrioxamine $\mathrm{B}(1 \mathrm{mM})$, were used as positive controls in Arnow's and $\mathrm{FeCl}_{3}$ assays, respectively. Milli-Q water was used as a negative control for both assays. A positive result for Arnow's assay was a color change to pink and a negative result remained colorless. Positive results for $\mathrm{FeCl}_{3}$ assays were color changes to dark red (1mM Desferrioxamine B), orange (trihydroxamate), or pink (dihydroxamate) (Lee et al., 2012). Broad spectra (250-700 nm in $50 \mathrm{~nm}$ increments) were measured for positive and weak positive results of $\mathrm{FeCl}_{3}$ assay using a Biomate 3 Spectrometer (Thermo Spectronic, Houston, TX, USA). 1mM Desferrioxamine B had a $\lambda_{\max }$ at $500 \mathrm{~nm}$. Hydroxamate positives had a $\lambda_{500 \mathrm{~nm}}$ greater than 0.260 ; weak hydroxamate positives were between 0.1 and 0.260 ; and hydroxamate negatives were less than 0.1 .

\section{$16 S$ rRNA Gene Sequencing}

DNA was extracted from siderophore-positive pure and mixed cultures and purified using the MoBio UltraClean Microbial DNA Isolation Kit (MoBio, Carlsbad, CA). The pure or mixed pool 16S rRNA gene was amplified with universal primers 46F (5'- GCYTAAYACATGCAAGTCG-3') and 1409R (5'-GTGACGGGCRGTGTGTRCAA-3') bacterial primers (1362 BP) (Northup et al., 2010). Reactions were carried out in a $25 \mu \mathrm{L}$ volume with 10× PCR buffer with $15 \mathrm{mM} \mathrm{Mg}^{2+}$, $0.3 \mu \mathrm{M}$ of each primer, $0.25 \mathrm{mM}$ of each dNTPs, $5 \mu \mathrm{g}$ of $50 \mathrm{mg} / \mathrm{mL}$ BSA (Ambion Austin, TX, USA) and 1U Ampli-Taq LD (Applied Biosystems, Foster City, CA, USA). PCR reactions were performed with an MJ thermocycler with the program, $94{ }^{\circ} \mathrm{C}$ for $5 \mathrm{~min}, 30$ cycles at $94{ }^{\circ} \mathrm{C}$ for $30 \mathrm{~s}, 55.5^{\circ} \mathrm{C}$ for $30 \mathrm{~s}, 72^{\circ} \mathrm{C}$ for $1.5 \mathrm{~min}$ and final extension at $72{ }^{\circ} \mathrm{C}$ for 7 min. Amplicons were purified using MoBio PCR Clean Up Kit (MoBio, Carlsbad, Calif.) and cloned using the TOPO TA Cloning kit (Invitrogen, Carlsbad, Calif.).

The 16S rRNA genes of all pure cultures and twelve clones from each mixed culture, randomly selected by coin flip, were sequenced with BigDye 1.1 using the T3 or T7 for the sense direction of the 16S rRNA gene. Sequencing was performed with the ABI Prism 3130 Automated DNA Sequencer at UNM-Molecular Biology Facility, Albuquerque, NM and an ABI Prism 3730xI Automated DNA Sequencer when sequenced at GENEWIZ Genomics, Danvers, Mass.

\section{Phylogenetic Analysis}

A total of 1102 16S rRNA gene sequences were analyzed for siderophore-strong and siderophore-weak, respectively (Table S2). Using Sequencer 5.1 (Gene Codes Corp., Ann Arbor, Mich.), ambiguous portions were trimmed to a minimum of 500 BP and edited. Chimeras were identified with QIIME v.1.9.1 (Caporaso et al., 2010) and removed. Sequences from each bacterial culture were assembled with $97 \%$ sequence similarity to identify unique clone types. Within the siderophore-strong and siderophore-weak groupings the sequences were assembled with $98 \%$ similarity to identify Operational Taxonomic Units (OTU). Using the longest representative sequence for each OTU, taxonomic assignments were identified using BLAST (Altschul et al., 1990). Representative sequences were assigned accession numbers in GenBank (Tables S3 and S4). A sequence alignment was performed using default parameters of EMBL-EBI webPRANK (http://www.ebi.ac.uk/goldman-srv/webprank/) and subsequently a similarity matrix was determined using a custom MATLAB script (Table S5). A maximum likelihood tree was constructed by using IQ-TREE web server: fast and accurate phylogenetic trees under maximum likelihood (http://iqtree.cibiv.univie.ac.at/) with 1000 replicates (Minh et al., 2013). The tree files were visualized and annotated with the Interactive Tree of Life (iTOL) v.3.5.3 program (http:// itol.embl.de/) and vector-drawing program Inkscape v.0.92.1 (https://inkscape.org).

\section{RESULTS}

The bacterial cultures from cave deposits collected from both the LT and ST parent cultures represented a potentially rich diversity of chemoorganoheterotrophic microorganisms exposed to multiple days or years of incubation for testing for the capability to produce siderophores. One hundred and seventy bacterial cultures, pure and mixed, were gathered from subcultures of LT and ST parent cultures (Tables 1 and 2). Eighty LT bacterial cultures were collected from top, middle, and bottom sample depths from four LT parent cultures. The majority of bacterial cultures collected from the same depth grouped together to form a representative sequence (data not shown). Forty-five percent $(n=36)$ of $\mathrm{LT}$ bacterial cultures were subcultured on $\mathrm{R} 2 \mathrm{~A}+\mathrm{FeCl}_{3}, 42.5 \%(n=34)$ were subcultured on $\mathrm{R} 2 \mathrm{~A}+\mathrm{MnCO}_{3}$, and 12.5 $\%(n=10)$ of were subcultured on $\mathrm{AIA}+\mathrm{FeCl}_{3}+\mathrm{MnCO}_{3}$ (Table 1). Ninety ST bacterial cultures were collected from 40 ST parent cultures. All ST bacterial cultures were subcultured on $1 / 2$ R2A (Table 2).

\section{Siderophores are Produced by LT and ST Bacterial Cultures}

The CAS assay was used to classify bacterial cultures according to detection zones of siderophore production that was measured from plating of a culture to the first day of CAS color change (Table 3 ). There was a range of color changes, including a dominant change to orange (hydroxamate) or clear. A CAS-color change to completely clear probably indicated carboxylate siderophores (Pérez-Miranda et al., 2007; Sullivan et al., 2012), but was detected using an agar overlay with a color change to white. We believe the addition of the indicator to the medium resulted in a white color in our study. We did not observe complete clearing. There were no color changes to purple (catechol). Thirty-six percent 
Table 3. Siderophore detection in LT $(n=80)$ and ST $(n=90)$ bacterial cultures.

\begin{tabular}{|c|c|c|c|c|c|c|c|}
\hline \multirow[b]{2}{*}{ Group } & \multirow{2}{*}{$\begin{array}{c}\text { Siderophore } \\
\text { Detection Levela }^{a}\end{array}$} & \multicolumn{5}{|c|}{ Days } & \multirow{2}{*}{$\begin{array}{c}\text { Total Cultures } \\
(\%)\end{array}$} \\
\hline & & $<10$ & $11-15$ & $16-20$ & $21-25$ & $>26$ & \\
\hline \multirow[t]{5}{*}{$\mathrm{LT}$} & Strong $(>2 \mathrm{~mm})$ & $\cdots$ & $7(9)$ & $1(1)$ & $2(3)$ & $18(23)$ & $28(36)$ \\
\hline & Weak $(<2 \mathrm{~mm})$ & $\cdots$ & $2(3)$ & $\cdots$ & $\cdots$ & $10(13)$ & $12(16)$ \\
\hline & None & $\ldots$ & $\ldots$ & $\ldots$ & $\ldots$ & $\ldots$ & $13(16)$ \\
\hline & $N G^{b}$ & $\cdots$ & $\ldots$ & $\ldots$ & $\cdots$ & $\ldots$ & $27(32)$ \\
\hline & Total (\%) & $0(0)$ & $9(12)$ & $1(1)$ & $2(3)$ & $28(36)$ & $80(100)$ \\
\hline \multirow[t]{5}{*}{ ST } & Strong $(>2 \mathrm{~mm})$ & $11(12)$ & $21(23)$ & $10(11)$ & $6(7)$ & $20(22)$ & $68(75)$ \\
\hline & Weak $(<2 \mathrm{~mm})$ & $\ldots$ & $1(1)$ & $\ldots$ & $\ldots$ & $\ldots$ & $1(1)$ \\
\hline & None & $\cdots$ & $\cdots$ & $\ldots$ & $\cdots$ & $\ldots$ & $15(17)$ \\
\hline & $N^{b}$ & $\ldots$ & $\ldots$ & $\ldots$ & $\ldots$ & $\ldots$ & $6(7)$ \\
\hline & Total (\%) & $11(12)$ & $22(24)$ & $10(11)$ & $6(7)$ & $20(22)$ & $90(100)$ \\
\hline
\end{tabular}

a. Zone of color change.

b. No growth (NG)- live bacteria cultures that did not grow on CAS media when transferred from Fe-limiting ISP4 media.

Numbers within parentheses are percentages (\%).

of the total LT bacterial cultures were strong siderophore producers, $16 \%$ were weak, and $16 \%$ had no detectable siderophore production, while $32 \%$ did not grow on the CAS assay (Table 3 ). In contrast to the LT cultures, the majority of ST bacterial cultures were strong siderophore producers (Table 3) with $75 \%$ percent of the total ST bacterial cultures strong siderophore producers, $1 \%$ were weak, and $17 \%$ had no detectable siderophore production. Seven percent of the ST bacterial cultures did not grow on the CAS assay (Table 3).

The period of time it took for the microbial siderophore production to manifest itself fell into five categories: less than 10 days, $11-15$ days, $16-20$ days, $21-25$ days and greater than 26 days. The majority, $36 \%$ of LT siderophores-producers, took greater than 26 days to manifest in contrast with no siderophores produced in less than 10 days. For ST siderophore-producers $24 \%$ took 11-15 days to manifest with the lowest production of siderophores, $7 \%$, by cultures in 21-25 days (Table 3). Overall, the ST siderophore production occurred more quickly than LT and may be related to their overall faster growth.

\section{Hydroxamate Rather than Catecholate Siderophores are Produced by LT and ST Bacterial Cultures}

To determine the preference of siderophore use by cave bacteria, the bacterial cultures were exposed to iron-limiting growth conditions and siderophore type was assessed from the supernatant after 53 days. Hydroxamate siderophores, determined by the $\mathrm{FeCl}_{3}$ assay color change of the supernatant, (color phenotypes shown in Fig. $3 \mathrm{C}$ ) were the dominant type of siderophores detected in our study. Hydroxamate siderophore detection was fairly even between ST and LT cultures (Fig. 3B), while catecholate siderophores, which were determined by the Arnow's assay color change from clear to pink of the supernatant, were rarely detected in our study (Fig. 3A).

Siderophore-producing Bacterial Cultures are Closely Related to Members of Proteobacteria (Alpha-, Beta-, and Gamma-), Actinobacteria, Firmicutes, and Bacteroidetes

A total of 982 16S rRNA genes were sequenced for strong siderophore producers and $12016 \mathrm{~S}$ rRNA genes for weak siderophore producers (Table S2). The total (982 sequences) siderophore-strong 16S rRNA gene sequences within the siderophore-strong class clustered into 85 representative bacterial operational taxonomic units (OTUs) (Fig. 4, Table S3). In contrast, the total (120 sequences) siderophore-weak class clustered into 14 representative bacterial OTUs (Fig. 5, Table S4). Together, the siderophore producing representative OTUs classified into Proteobacteria (Alpha-, Beta-, and Gamma-), Actinobacteria, Firmicutes, and Bacteroidetes (Figs. 4 and 5).

Proteobacteria was the most abundant phylum for siderophore producers. Gammaproteobacteria, found only in the siderophore strong producers, had the most OTUs overall. Within the strong Proteobacteria siderophore producers there were 44 OTUs, classified as 12 Alpha-, 14 Beta-, and 18 Gamma- (Fig. 4, Table S3). Siderophore weak producers only had six OTUs, which were classified as four Alpha- and two Beta- (Fig. 5, Table S4). No Delta-, Zeta-, or Epsilonproteobacteria were classified in either group.

Alphaproteobacteria had the most genera represented, with eight strong siderophore producers and three weak siderophore producers, even though Gammaproteobacteria overall had the most OTUs (Figs. 4 and 5). Sphingopyxis was the only genus identified in both siderophore producing groups (strong and weak), as opposed to the following genera, which were only identified in the siderophore strong group: Mycoplana, Sinorhizobium, Phenylobacterium, Pheny- 


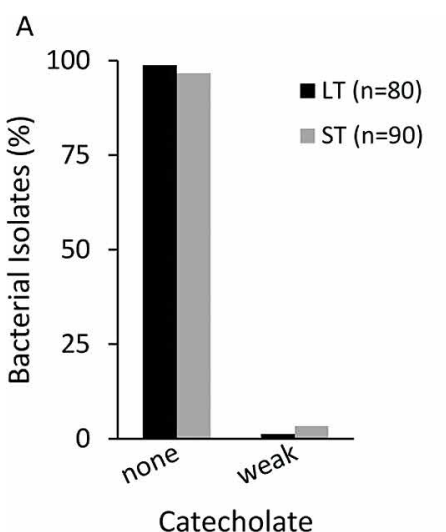

C

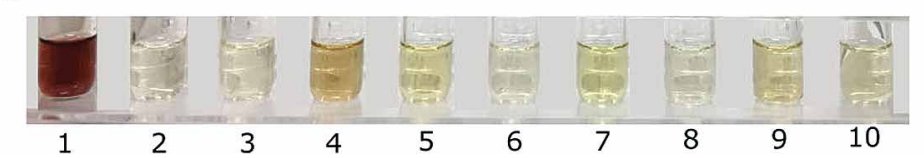

Figure 3. The percentage of Long-term (LT) and Short-term (ST) bacteria cultures producing Catecholate $(\mathrm{A})$ and Hydroxamate $(\mathrm{B})$ siderophores. C) Varying color phenotypes of Hydroxamate-type $\mathrm{FeCl}_{3}$ Assay. Lane 1-positive control, Desferrioxamine B (1mM), 2-negative control, Milli-Q $\mathrm{H}_{2} \mathrm{O}$, 3-negative control, uninoculated media, 4-strong-positive, 5-weak-positive, 6-no hydroxamate, 7-weak positive, 8-no hydroxamate, 9-weak positive, and 10 -weak positive.

Gammaproteobacteria in the siderophore strong group (Fig 4 Ta T3). The other three most abundant Proteobacteria were two Betaproteobacteria and one Alphaproteobacteria (Table S3). None of the siderophore weak producers had a representative OTU with greater than 20 sequences (Table S4).

Overall, Proteobacterial classes Beta- and Gamma-, in the strong siderophore producers group, include genera that are known as siderophore producers. In contrast, Alphaproteobacteria only had two genera, Sinorhizobium and Sphingomonas, related to known siderophore producers in the siderophore-strong and -weak, respectively (Figs. S1 and S2). The majority of the seven most abundant sequences that had greater than 20 sequences each are known siderophore producers, except for Sphingopyxis, which was not previously known to produce siderophores. Most of the close relatives of Proteobacteria siderophore producers can inhabit low nutrient environments, including other carbonate caves, can break down and recycle aromatic-containing structures, are possibly endosymbionts, and can thrive in heavy metal environments (Figs. S1 and S2).

Actinobacteria was the second most abundant phylum of siderophore producers. Within the strong and weak siderophore producers there were 16 and three representative OTUs, respectively, with the majority identified as closely related to known siderophore producers (Figs. 4 and 5). In the siderophore strong group, Rhodococcus, Norcardia, Microbacterium, Arthrobacter, and two uncultured bacteria: an uncultured Yanshan Mountain clone and a crude oil-degrading strain TPKD2 were among the genera identified (Fig. S1, Table S3). In the siderophore weak group, Lentzea and Knoellia were among the genera identified (Fig. S2, Table S4). Streptomyces was identified in each group (Tables S3 and S4), however it was not the most abundant genus. Instead, Norcardia coeliaca, Curtobacterium luteum, Microbacterium sp., Arthrobacter methylotrophus, Arthrobacter siccitolerans, and Lentzea violacea all had greater than 20 sequences each (Tables S3 and S4). Surprisingly, not all Actinobacteria genera identified are known siderophore producers. Lentzea (EU593719) and Knoellia (LN774289), not previously described as siderophore producers, were identified in karst limestone and cave air, respectively, and are possibly common to aphotic subsurface environments (Fig. S2, Table S4).

Bacteroidetes was the third most abundant phylum for siderophore producers. Within the strong and weak siderophore producers there were 14 and 2 total representative OTUs, respectively, with the majority identified as unknown siderophore producers (Figs. 4 and 5). There were no similar genera identified in each group, however Chitinophaga, was identified within the weak siderophore producing group (Table S4). In contrast, for the siderophore strong group, Hymenobacter, Olivibacter, Flavihumibacter, and four uncultured clones: an uncultured mineral photocatalysis clone, uncultured clone NDB4, uncultured soil diffusion chamber system CCRA clone, and uncultured Sphingobacteriales bacterial clone were all identified (Fig. S2, Table S3). The most abundant Bacteroidetes OTUs that had greater than 20 sequences in 


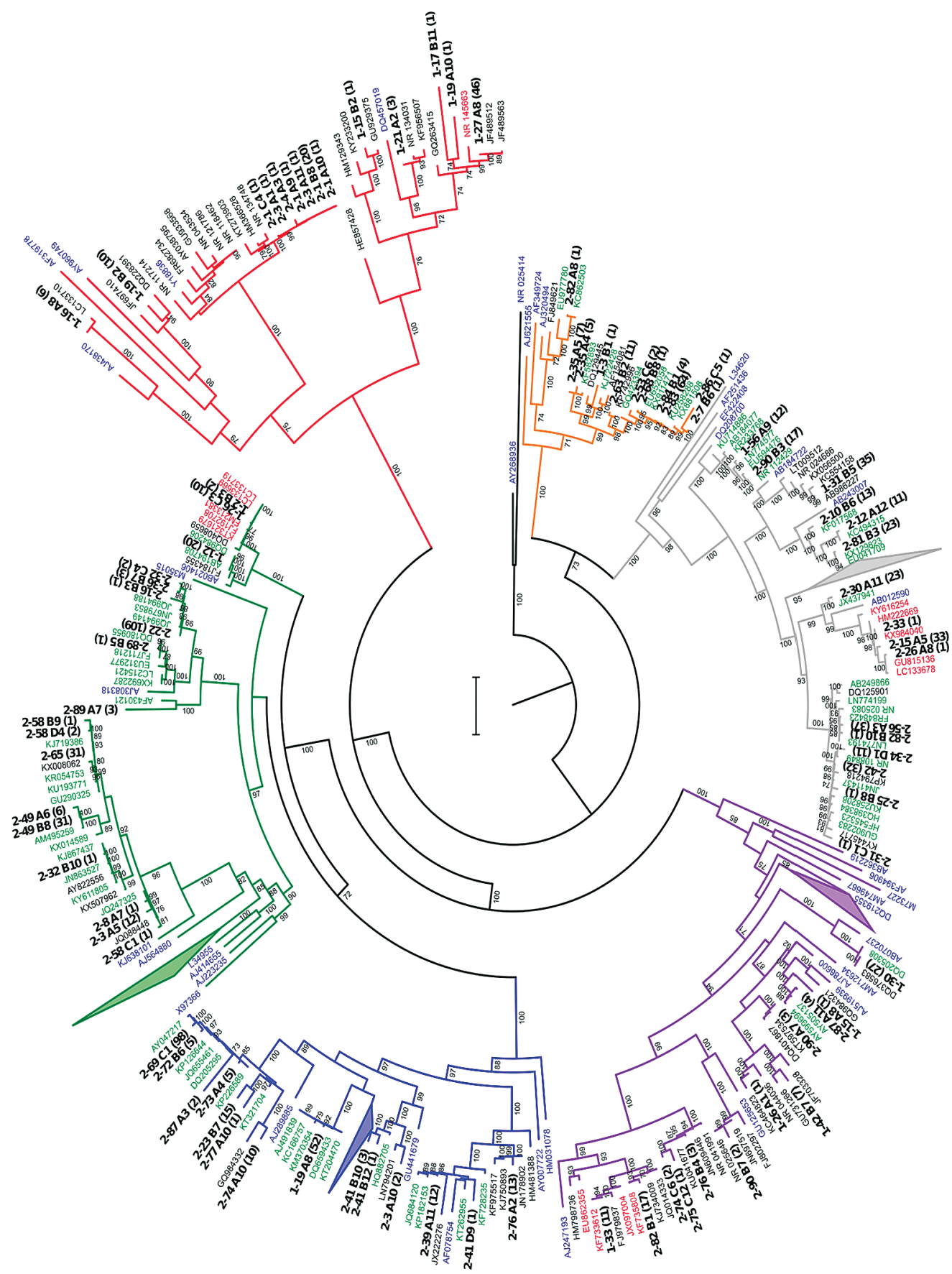

Figure 4. Phylogenetic tree of the closest bacterial relatives to siderophore-strong representative OTUs. Ultrabootstrap values are $>70 \%$ or otherwise stated on 1000 replicates. The scale bar corresponds to 0.1 nucleotide substitutions per site. Representative OTU sequences code: 1-Long-term and 2-Short-term, culture number, letter-clone number, and numbers of clones per representative sequence are in parenthesis (Supplemental Table S3). The numbers of clones per representative sequence are in parenthesis. Color code of branches: Grey-Actinobacteria, Orange-Firmicutes, Purple-Alphaproteobacteria, Blue-Betaproteobacteria, Green-Gammaproteobacteria, and Red-Bacteroidetes. Name color code: Blue-reference strain, Green-a member of the same genus is known as a siderophore producer, Red-a member of the same genus is known as a non-siderophore producer, and Black-strain is uncultured (UC) or has not been reported as a siderophore producer. Triangles are collapsed reference strain clades. bacteria may possibly produce novel siderophores or have additional microbial recycling roles, such as metabolism of aromatic rings (Figs. S1 and S2, Tables S3 and S4). each representative sequence were uncultured bacterial clones (Table S3). Many of the closest relatives are related to bacteria that live in water, are inhabitants of low-nutrient environments, and can live in low radioactive and chemical waste sites (Tables S3 and S4).

Firmicutes was the least abundant phylum for siderophore producers. Within the strong and weak siderophore producers there were 11 and 3 total representative OTUs, respectively, with the majority identified to be related to known siderophore producers (Figs. 4 and 5, Tables S3 and S4). Bacillus was identified in both siderophore producing groups, along with Paenibacillus, Geobacillus, and one uncultured clone, an uncultured urban aerosol clone in the siderophore strong producer group (Fig. 4, Table S3). Additionally, Bacillus was the most abundant Firmicutes OTU with greater than 20 sequences (Table S3). Many of the closest relatives are related to bacteria that live in the ocean near geothermal mineral deposits and hydrocarbon seeps, are inhabitants of low nutrient clean rooms, are endophytic, or live in the soil (Figs. S1 and S2, Tables S3 and S4).

Interestingly, there were genera identified that were not previously known as siderophore producers in both the siderophore-strong and -weak groups. Genera of the siderophore strong producers were identified as Brevundimonas sp. (Alphaproteobacteria), Pseudoxanthomonas spp. (Gammaproteobacteria), and Microbacterium spp. (Actino(red text, Figs. 4 and 5). These 


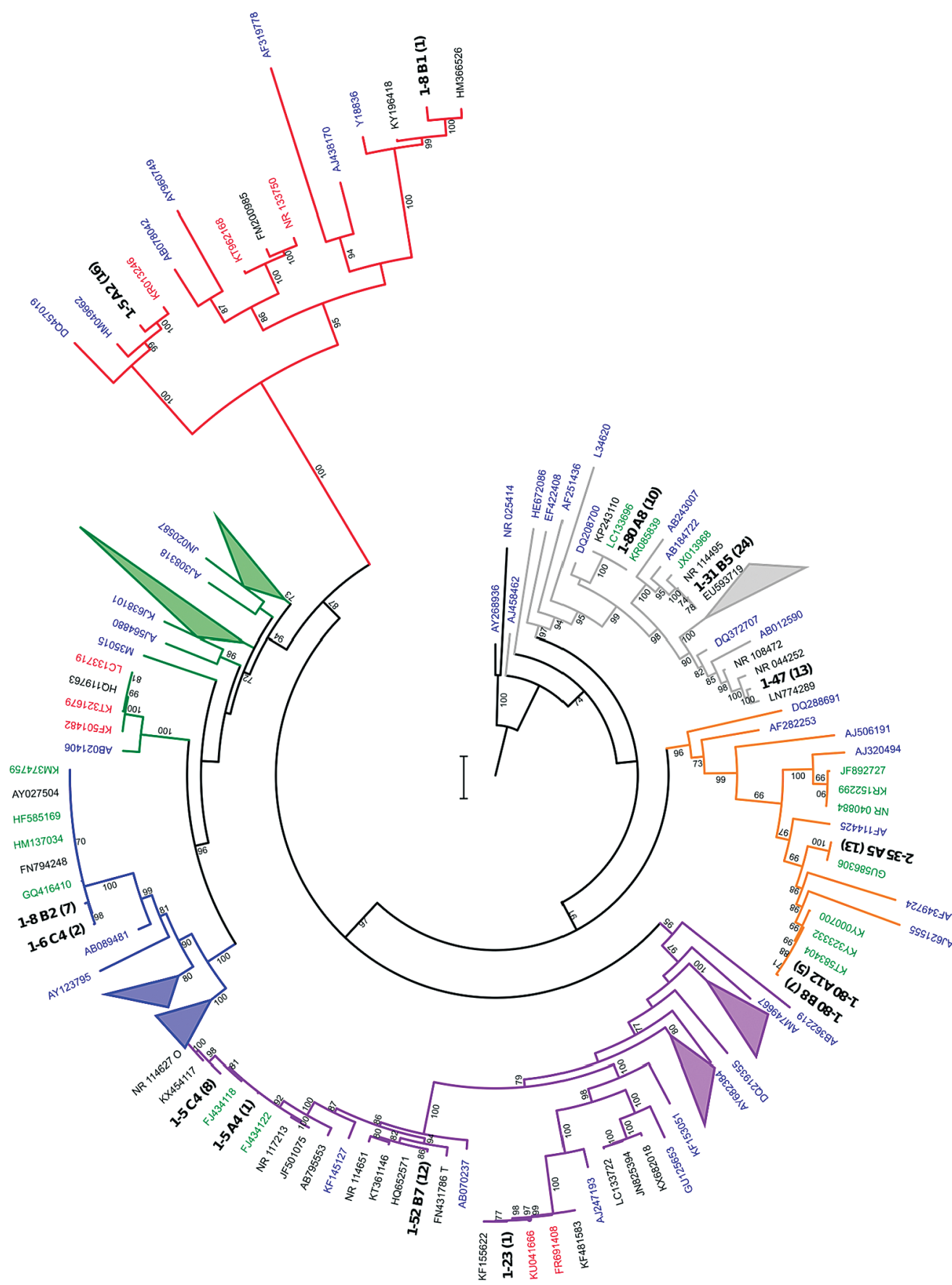

Figure 5. Phylogenetic tree of the closest bacterial relatives to siderophore-weak representative OTUs. Ultrabootstrap values are $>70 \%$ or otherwise stated as 1000 replicates. The scale bar corresponds to 0.1 nucleotide substitutions per site. Representative OTU sequences code: 1-Long-term and 2-Short-term, culture number, letter-clone number, and numbers of clones per representative sequence are in parenthesis (Supplemental Table S4). The numbers of clones per representative sequence are in parenthesis. Color code of branches: Grey-Actinobacteria, Orange-Firmicutes, Purple-Alphaproteobacteria, Blue-Betaproteobacteria, Green-Gammaproteobacteria, and Red-Bacteroidetes. Name color code: See Figure 4 legend. ), and Chitinophaga sp. (Bacteroidetes). These bacterial genera have all been identified in oligotrophic caves or other cave studies (Barton et al., 2007; Chen et al., 2009; Ghosh et al., 2017) and along with potential siderophore production could contribute to the survival of an oligotrophic-dwelling community by offering non-siderophore related characteristics. The non-siderophore characteristics are metabolism of aromatic ring-containing compounds by $\mathrm{Mi}$ crobacterium sp. (de los Cobos-Vasconcelos et al., 2012; Jin et al., 2017), the production of proteases that are able to function in highly alkaline conditions by Pseudoxanothomonas sp. (Salwan et al., 2010), the ability to mobilize Fe, Al, Si, 
an K from rock by Chitinophaga sp. (Wang et al., 2014), and the ability to adapt to oligotrophic environmental conditions of Brevundimonas sp. (Dworkin, 2002).

Survival in an oligotrophic deep cave environment appears to require several non-phototrophic microbial metabolic strategies (Tomczyk-Zak and Zielenkiewicz, 2016). We selected for chemolithoheterotrophic and heterotrophic bacteria from Lechuguilla and Spider Caves, CCNP. Chemolithoheterotrophic bacteria, also known as mixotrophs, derive their energy from inorganic chemicals, but rely on organic chemicals in the environment for carbon needs. No obligate chemolithotrophs were identified in this study, but four genera, Ralstonia sp. (Libert et al., 2004), Burkholderia sp. (Libert et al., 2004), Cupriavidus sp. (van Houdt et al., 2009) and Achromobacter sp. (Ehsani et al., 2019), were identified and are known to oxidize hydrogen as an energy source (chemolithotrophic). These bacteria were isolated from metal-rich deep oligotrophic basin water (Ralstonia sp. and Burkholderia sp.) and sediments (Cupriavidus sp.) and soil (Achromobacter sp.) environments, but what their specific metabolic roles are in the cave is an aim for future research.

We observed that cave bacteria prefer hydroxamate siderophores, possibly due to the overall oligotrophic nature of CCNP caves. Catecholate siderophore production was rarely preferred by cave microorganisms in our study, which most likely is due to the higher energy cost of production. The preference for the hydroxamate siderophores is possibly due to the less complex biosynthesis of hydroxamate siderophores. Hydroxamate siderophores are generally made from available amino alcohol building blocks; derivatives from amino acids (Challis, 2005), which are often present in the environment (Moura et al., 2013). In addition, previous work showed directly that hydroxamate siderophores can be recycled (Emery, 1971; Hartmann and Braun, 1980; Braun et al., 1984; Hannauer et al., 2010). By utilizing readily-available compounds in their local environments that have been shown to be recycled, bacteria are potentially able to limit the energetic cost to produce and recycle hydroxamate siderophores. Whether siderophore production by cave microorganisms is used primarily for ferric iron acquisition, or for nutrient exchange within a mixed culture, or both, remains to be determined.

Hydroxamate siderophores have a binding constant range of $10^{22}$ to $10^{32} \mathrm{M}^{-1}$ (Miethke, 2013) whereas the catecholate-model, enterochelin, had a binding range of $10^{52} \mathrm{M}^{-1}$ (Saha et al., 2016). Although we identified hydroxamate siderophore production as a majority, we speculate that it is due to the contrasting environments in which catecholate and hydroxamate siderophores are commonly found. Gram-negative bacteria, specifically pathogens like Escherichia coli, are well known catecholate siderophores producers (Winkelmann, 2002) and would require extremely high ferric $\left(\mathrm{Fe}^{3+}\right)$ binding affinities if they are to compete with host iron binding proteins for iron (Chu et al., 2010). Thus, combined with the higher likelihood that catecholate siderophores require more energy to make, a luxury not available for bacteria surviving in oligotrophic caves, hydroxamate siderophores would be sufficient to gather needed ferric $\left(\mathrm{Fe}^{3+}\right)$ iron from the surrounding cave environment.

Interestingly, the CAS assay gave an indication that carboxylate-type of siderophores might be produced by mixed cave cultures. Sullivan et al., (2012) reported a range of CAS assay color changes that, along with orange and purple that indicate hydroxamate and catechol, respectively, a color change to clear indicated a carboxylate-type. Although we didn't find any blue color change to clear results, we did observe at least three mixed cultures to have a color change to white and nine mixed cultures that were siderophore positive, but tested negative for the hydroxamate and catechol tests (data not shown). We also identified several Rhizobium spp. in the siderophore-strong group including Rhizobium meliloti strain DM4, which are known carboxylate siderophore producer (Ali et al., 2013). Determining whether there are carboxylate siderophores from the mixed category would be the focus of a future study.

Mixed cultures (two or more organisms in a culture) can allow for a full suite of interactions among microorganisms in the environment, but interactions can be unstimulated if pure cultures were obtained (Nai and Meyer, 2018). Because oligotrophic cave environments may select for potential microbial consortial microorganisms (Barton and Jurado, 2007) and siderophores have potential to promote nutrient exchange (D'Onofrio et al., 2010), mixed cultures were included to determine siderophore presence in a low nutrient cave environment. Approximately half of the siderophore-producing cultures were mixed cultures with 2-6 genera/culture. Hershey et al., (2004) observed siderophore cross feeding that allowed non-growing Lechuguilla bacteria to grow but didn't take into consideration whether the timing of the production of siderophores is affected by pure or mixed cultures. A future study would determine whether mixed cultures are obligate consortial microorganisms and whether the timing and production of siderophores by pure or mixed cultures are shared among the bacterial community.

How representative our study of CCNP caves are to other cave systems is not known in detail, but Lechuguilla and Spider Caves were chosen as our study sites because of their abundant levels of ferric $\left(\mathrm{Fe}^{3+}\right)$ iron in visible deposits on cave walls (Northup et al., 2003; Spilde et al., 2005). Such deposits are not rare but are also not abundant in carbonate caves. We hypothesized that these ferromanganese deposits (FMD) that line the cave walls would be a valuable source of ferric iron needed for cellular processes. Another key factor that makes these caves different from some other caves is that they occur in a semi-arid environment and, as a result, are more oligotrophic than caves in areas with more 
surface precipitation, which could limit the amount of energy available for siderophore production. In addition to limited surface precipitation, the surface soils above carbonate caves are highly oligotrophic due to low carbon levels (Ortiz et al., 2014), resulting in less infiltration of nutrients to fuel metabolic processes. We also hypothesize that surface soil siderophore producers either do not infiltrate into the cave, or if they do, rarely survive. Lavoie et al., (2017) showed that in a comparison of semi-arid lava tube cave microbial mats to surface soils overlying the cave that there was only an $11.2 \%$ OTU overlap in the microbial diversity. These conditions suggest that semi-arid caves are likely very different from caves in regions with more rainfall.

Particularly relevant to siderophore production in our study caves, is the study by Levy (2007), who showed that the amount of $\mathrm{Fe}$ in drip water entering Lechuguilla Cave pools was below detectable limits $\left(<0.06 \mathrm{mg} \mathrm{L}^{-1}\right)$. Thus, in areas without FMD in these caves, iron is likely more limited. Taken together, siderophore usage by microorganisms is preferred in oxidized environments with available ferric $\left(\mathrm{Fe}^{3+}\right)$ iron sources, both of which Lechuguilla and Spider caves have. To understand how representative the microorganisms from these caves are in terms of siderophore production, caves that occur in areas with more rainfall and hence more nutrients and that lack substantial iron-rich secondary deposits would need to be investigated and compared.

\section{CONCLUSIONS}

Our study has identified potential novel siderophore producers that may lead to the identification of new compounds or the roles that siderophores have within mixed microbial relationships. In addition to chelating ferric $\left(\mathrm{Fe}^{3+}\right)$ iron from the environment, siderophores can enhance growth or protect plants from pathogens, are recognized and used by both fungi and bacteria, serve in soil mineral weathering, and are involved directly or indirectly in bioremediation of environmental pollutants, including heavy metals and hydrocarbons (Ahmed and Holmström, 2014). By understanding the specific role of siderophores in the natural cave environment, which lacks plants and contains minerals, we can enhance our understanding of the context in which siderophores are produced and how cave bacteria can live in this oligotrophic environment.

The identification of siderophore producers from mixed cultures collected from the cave environment revealed the rich diversity of cave bacteria. Understanding the intimate interactions among bacteria in caves can offer clues to understanding how these organisms survive for the long term in this otherwise low-nutrient environment. This rich diversity of bacteria helps promote an ongoing critical search for new antibiotics, potentially sideromycins, for treatment of antibiotic-resistant microorganisms and novel siderophores for bioremediation.

\section{ACKNOWLEDGEMENTS}

We thank Cristina Takacs-Vesbach, Cliff Dahm, and Penelope Boston for helpful discussions. We are grateful to Ara Winter, Jenny Hathaway, Simon Hathaway, Nicole Caimi, and Anthony Rigoni for technical assistance. We thank the staff at the Cave Resource Office at Carlsbad Caverns National Park and Patricia Seiser for their invaluable assistance with sample collection. We thank Leslie Melim for her assistance in describing the study sites. We thank the UNM Molecular Biology Core Facilities for equipment and DNA sequencing, supported by the National Institute of General Medical Sciences and the National Institutes of Health under award number P30 GM110907. The research reported in this publication is solely the responsibility of the authors and does not represent the official views of the National Institutes of Health. We are grateful to David John and team for their invaluable assistance with perspectives and support. We are grateful to Shelly Payne and anonymous reviewers for suggestions that improved the manuscript. The authors thank the Journal of Cave and Karst Studies Associate Editors and Advisory Board for their encouragement and constructive criticism. Photo in Figure 1 courtesy of Kenneth Ingham.

This work was supported by the Initiative to Maximize Student Development (IMSD) at UNM Biology National Institute of Health (NIH) Grant \#GM060201, the ASM Robert D. Watkins Graduate Research Fellowship sponsored by the American Society of Microbiology (ASM), The Navajo Nation Graduate Fund, and UNM Academic Science Education and Research Training (ASERT) program funded by the Institutional Research and Academic Career Development Award (IRACDA) NIH Grant \#K12GM088021 for research supplies and training support for Dr. Duncan.

\section{REFERENCES}

Ahmed, E., and Holmström, S.J.M., 2014, Siderophores in environmental research: roles and applications: Microbial Biotechnology, v. 7, p. 196-208. https://doi.org/10.1111/1751-7915.12117

Ali, S.S., and Vidhale, N.N., 2013, Bacterial siderophore and their application: a review: International Journal of Current Microbiology and Applied Sciences, v. 2, p. 303-312.

Altschul, S. F., Gish, W., Miller, W., Myers, E.W., 1990, Basic local alignment search tool: Journal of Molecular Biology, v. 215, p. 403-410. https://doi.org/10.1016/S0022-2836(05)80360-2

Arnow, L.E, 1937, Colorimetric determination of the components of 3,4-dihydroxphenylalaninetyrosine mixtures: Journal of Biological Chemistry, v. 118, p. $531-537$.

Atlas, R M., 2004, Handbook of microbiological media: Boca Raton, London, New York, Washington, D.C., CRC Press LLC, 208-209 p.

Barton, H A., and Jurado, V., 2007, What's up down there? Microbial diversity in caves: Microbe, v. 2, p. 132-138. 
Barton, H.A., Taylor, N.M., Kreate, M.P., Spinger, A.C., Oehrle, S.A., and Bertog, J.L., 2007, The impact of host rock geochemistry on bacterial community structure in oligotrophic cave environments: International Journal of Speleology, v. 36, p. 93-104. https://doi.org/10.5038/1827806x.36.2.5

Biessy, A., Novinscak, A., Blom, J., Léger, G., Thomashow, L.S., Cazorla, F.M., Josic, D., and Filion, M., 2018, Diversity of phytobeneficial traits revealed by whole-genome analysis of worldwide-isolated phenazine-producing Pseudomonas spp.: Environmental Microbiology, v. 21, p. 437-455. https://doi.org/10.1111/1462-2920.14476

Boiteau, R.M., Mende, D.R., Hawco, N.J., Mcllvin, M.R., Fitzsimmons, J.N., Saito, M.A., Sedwick, P.N., DeLong, E.F., and Repeta, D.J., 2016, Siderophore-based microbial adaptations to iron scarcity across the eastern Pacific Ocean: Proceedings of the National Academy of Sciences of the United States of America, v. 113, p. 14237-14242. https://doi.org/10.1073/pnas.1608594113

Braun, V., Brazel-Faisst, C., and Schneider, R., 1984, Growth stimulation of Escherichia coli in serum by iron(III) aerobactin: Recycling of aerobactin, FEMS Microbiology Letters, v. 21, p. 99-103. https://doi.org/10.1111/j.1574-6968.1984.tb00193.x

Brusseau, M., Pepper, I., and Gerba, C., 2019, Environmental and Pollution Science, Elsevier Science \& Technology, $3^{\text {rd }}$ Edition, ProQuest Ebook Central, p. 2-20. https://ebookcentralproquest.com/lib/unm/detail.action?doclD=297063

Bundy, R.M., Boiteau, R.M., McLean, C., Turk-Kubo, K.A., Mcllvin, M.R., Saito, M.A., Van Mooy, B.A.S., and Repeta, D.J., 2018, Distinct siderophores contribute to iron cycling in the mesopelagic at station ALOHA: Frontiers in Marine Science, v. 5, p. 1-15. https://doi.org/10.3389/ fmars.2018.00061

Caporaso, J.G., Kuczynski, J., Stombaugh, J., Bittinger, K., Bushman, F.D., Costello, E.K., Fierer, N., Peña, A.G., Goodrich, J.K., Gordon, J.I., Huttley, G.A., Kelley, S.T., Knights, D., Koenig, J.E., Ley, R.E., Lozupone, C.A., McDonald, D., Muegge, B.D., Pirrung, M., Reeder, J., Sevinsky, J.R., Turnbaugh, P.J., Walters, W.A., Widmann, J., Yatsunenko, T., Zaneveld, J., and Knight, R., 2010, QIIME allows analysis of high-throughput community sequencing data: Nature Methods, v. 7, p. 335-336. https://doi.org/10.1038/nmeth.f.303

Challis, G.L., 2005, A widely distributed bacterial pathway for siderophore biosynthesis independent of nonribosomal peptide synthetases: ChemBioChem, v. 6, p. 601-611. https://doi.org/10.1002/cbic.200400283

Chen, Y., Wu, L., Boden, R., Hillebrand, A., Kumaresan, D., Moussard, H., Baciu, M., Lu, Y., and Colin Murrell, J., 2009, Life without light: microbial diversity and evidence of sulfur- and ammonium-based chemolithotrophy in Movile Cave: The ISME Journal, v. 3, p. 1093. https://doi. org/10.1038/ismej.2009.57

Chu, B., Garcia-Herrero, A., Johanson, T., Krewulak, K., Lau, C., Peacock, R. S., Slavinskaya, Z., and Vogel, H., 2010, Siderophore uptake in bacteria and the battle for iron with the host: A bird's eye view: Biometals, v. 23, p. 601-611. https://doi.org/10.1007/s10534-010-9361-x

Dave, B., Anshuman, K., and Hajela, P., 2006, Siderophores of halophilic archaea and their chemical characterization: Indian Journal of Experimental Biology, v. 44, p. 340-344.

de los Cobos-Vasconcelos, D., Ruiz-Ordaz, N., Galíndez-Mayer, J., Poggi-Varaldo, H., Juàrez-Ramírez, C., and Aarón, L.M., 2012, Aerobic biodegradation of a mixture of sulfonated azo dyes by a bacterial consortium immobilized in a two-stage sparged packed-bed biofilm reactor: Engineering in Life Sciences, v. 12, p. 39-48. https://doi.org/10.1002/elsc.201000227

D'Onofrio, A., Crawford, J.M., Stewart, E.J., Witt, K., Gavrish, E., Epstein, S., Clardy, J., and Lewis, K., 2010, Siderophores from neighboring organisms promote the growth of uncultured bacteria: Chemistry \& Biology, v. 17, p. 254-264. https://doi.org/10.1016/j.chembiol.2010.02.010

Dworkin, M. (ed), 2002, The Prokaryotes: An Evolving Electronic Resource For the Microbiological Community: Springer-Verlag, New York.

Ehsani, E., Dumolin, C., Arends, J.B.A., Kerckhof, F-M., Hu, X., Vandamme, P., and Boon, N., 2019, Enriched hydrogen-oxidizing microbiomes show a high diversity of co-existing hydrogen-oxidizing bacteria: Applied Microbiology and Biotechnology, v. 103, p. 8241-8253. https://doi. org/10.1007/s00253-019-10082-z

Emery, T., 1971, Role of ferrichrome as a ferric ionophore in Ustilago sphaerogena: Biochemistry, v. 10, p.1483-1488.

Ghosh, S., Paine, E., Wall, R., Kam, G., Lauriente, T., Sa-ngarmangkang, P.C., Horne, D., and Cheeptham, N., 2017, In situ cultured bacterial diversity from Iron Curtain Cave, Chilliwack, British Columbia, Canada: Diversity, v. 9, p. 36. https://doi.org/10.3390/d9030036

Glick, B.R., 2003, Phytoremediation: synergistic use of plants and bacteria to clean up the environment: Biotechnology Advances, v. 21, p. 383-393. https://doi.org/10.1016/S0734-9750(03)00055-7

Gong, Y., Bai, J.-L., Yang, H.-T., Zhang, W.-D., Xiong, Y.-W., Ding, P., and Qin, S., 2018, Phylogenetic diversity and investigation of plant growth-promoting traits of actinobacteria in coastal salt marsh plant rhizospheres from Jiangsu, China: Systematic and Applied Microbiology, v. 41, p. 516-527. https://doi.org/10.1016/j.syapm.2018.06.003

Gulden, B., 2019, USA Longest Caves: The National Speleological Survey (NSS) Geo2 Long \& Deep Caves, [http://caverbob.com/usalong.htm], April 7, 2019.

Hanaka, A., Ozimek, E., Majewska, M., Rysiak, A., and Jaroszuk-Ściseł, J., 2019, Physiological diversity of Spitsbergen soil microbial communities suggests their potential as plant growth-promoting bacteria: International Journal of Molecular Sciences, v. 20, p.1207. https://doi. org/10.3390/ijms20051207

Hannauer, M., Barda, Y., Mislin, G.L.A., Shanzer, A., and Schalk, I.J., 2010, The ferrichrome uptake pathway in Pseudomonas aeruginosa involves an iron release mechanism with acylation of the siderophore and recycling of the modified desferrichrome: Journal of Bacteriology, $v$. 192, p. 1212-1220. https://doi.org/10.1128/JB.01539-09

Hartmann, A., and Braun, V., 1980, Iron transport in Escherichia coli: Uptake and modification of ferrichrome: Journal of Bacteriology, v. 143, p. $246-255$.

Hayes, P.T., 1964, Geology of the Guadalupe Mountains, New Mexico, in U.S. Geological Survey Professional Paper, Volume 446, p. 11, Washington, D.C., U.S. Government Print Office.

Hershey, O.S., Akel, Z., and Barton, H.A., 2014, Siderophore crossfeeding in cave microbes: General Meeting of the American Society for Microbiology, Boston, Massachusettes, Abstracts, p. 2218.

Hider, R.C., and Kong, X., 2010, Chemistry and biology of siderophores: Natural Products Report, v. 27, p. 637-657. https://doi.org/10.1039/ B906679A

Hill, C.A., 1987, Geology of Carlsbad Cavern and other caves in the Guadalupe Mountains, New Mexico and Texas, New Mexico Bureau of Mines and Mineral Resources Bulletin 117, Socorro, N.M., 150 p.

Hill, C.A., Forti, P., 1997, Cave minerals of the world (2nd edn.), National Speleological Society, Huntsville, 464 p.

Inglis, J.R. (ed), 2008, Ringer's solution (pH 7.3-7.4): Cold Spring Harbor Protocols. https://doi.org/10.1101/pdb.rec11273

Jin, J., Yao, J., Liu, W., Zhang, Q., and Liu, J., 2017, Fluoranthene degradation and binding mechanism study based on the active-site structure of ring-hydroxylating dioxygenase in Microbacterium paraoxydans JPM1: Environmental Science and Pollution Research, v. 24, p. 363-371. https://doi.org/10.1007/s11356-016-7809-4 
Khan, A., Singh, P., and Srivastava, A., 2018, Synthesis, nature and utility of universal iron chelator-Siderophore: A review: Microbiological Research, v. 212-213, p. 103-111. https://doi.org/10.1016/j.micres.2017.10.012

Lavoie, K.H., Winter, A.S., Read, K J.H., Hughes, E.M., Spilde, M.N., and Northup, D.E., 2017, Comparison of bacterial communities from lava cave microbial mats to overlying surface soils from Lava Beds National Monument, USA: PLOS ONE, v.12, p. e0169339. https://doi. org/10.1371/journal.pone.0169339

Lee, J., Postmaster, A., Soon, H.P., Keast, D., and Carson, K.C., 2012, Siderophore production by actinomycetes isolates from two soil sites in Western Australia: Biometals, v. 25, p. 285-296. https://doi-org.libproxy.unm.edu/10.1007/s10534-011-9503-9

Levy, D.B., 2007, Oxidation-reduction chemistry of Lechuguilla Cave seepage: Journal of Cave and Karst Studies, v. 69, p. $351-358$.

Libert, M-F., Sellier, R., Cournac, L., Cournac, L., Chapon, V., and Heulin, T., 2004, Molecular hydrogen from water radiolysis as an energy source for bacterial growth in a basin containing irradiating waste: FEM Microbiology Letter, v. 240, p. 155-162. https://doi.org/10.1016/j. femsle.2004.09.025

Mawji, E., Gledhill, M., Milton, J.A., Tarran, G.A., Ussher, S., Thompson, A., Wolff, G A., Worsfold, P.J., and Achterberg, E.P., 2008, Hydroxamate siderophores: Occurrence and importance in the Atlantic Ocean: Environmental Science \& Technology, v. 42, p. 8675-8680. https://doi. org/10.1021/es801884r

Miethke, M., 2013, Molecular strategies of microbial iron assimilation: From high-affinity complexes to cofactor assembly systems: Metallomics, v. 5, p. 15-28. https://doi.org/10.1039/c2mt20193c

Minh, B.Q., Nguyen, M.A.T., and von Haeseler, A., 2013, Ultrafast approximation for phylogenetic bootstrap: Molecular Biology and Evolution, v. 30, p. 1188-1195. https://doi.org/10.1093/molbev/mst024

Moura, A., Savageau, M.A., and Alves, R., 2013, Relative amino acid composition signatures of organisms and environments, PLOS ONE, v. 8 , p. e77319. https://doi.org/10.1371/journal.pone.0077319

Nai, C., and Meyer, V., 2017, From axenic to mixed cultures: Technological advances accelerating a paradigm shift in microbiology, Trends in Microbiology, v. 26, p. 538-554. https://doi.org/10.1016/j.tim.2017.11.004

Neilands, J.B., 1981, Iron absorption and transport in microorganisms: Annual Review of Nutrition, v. 1, p. 27-46. https://doi.org/10.1146/annurev. nu.01.070181.000331

Northup, D.E., Barns, S.M., Yu, L.E., Spilde, M.N., Schelble, R T., Dano, K.E., Crossey, L.J., Connolly, C.A., Boston, P.J., Natvig, D.O., and Dahm, C.N., 2003, Diverse microbial communities inhabiting ferromanganese deposits in Lechuguilla and Spider Caves: Environmental Microbiology, v. 5, p. 1071-1086. https://doi.org/10.1046/j.1462-2920.2003.00500.x

Northup, D.E., Dahm, C.N., Melim, L.A., Spilde, M.N., Crossey, L.J., Lavoie, K.H., Mallory, L.M., Boston, P.J., Cunningham, K.I., and Barns, S.M., 2000, Evidence for geomicrobiological interactions in Guadalupe Caves: Journal of Cave and Karst Studies, v. 62, p. 80-90.

Northup, D.E., and Lavoie, K.H., 2001, Geomicrobiology of caves: A review: Geomicrobiology Journal, v.18, p. 199-222. https://doi-org.libproxy. unm.edu/10.1080/01490450152467750

Northup, D E., Snider, J.R., Spilde, M.N., Porter, M.L., van de Kamp, J.L., Boston, P.J., Nyberg, A.M., and Bargar, J.R., 2010, Diversity of rock varnish bacterial communities from Black Canyon, New Mexico: Journal of Geophysical Research: Biogeosciences, v. 115. https://doi. org/10.1029/2009JG001107

Ortiz, M., Legatzki A., Neilson, J.W., Fryslie, B., Nelson, W.M., Wing, R.A., Soderlund, C.A., Pryor, B.M., and Maier, R.M., 2014, Making a living while starving on the dark: Metagenpomic insights into the energy dynamics of a carbonate cave; The ISME Journal, v. 8, p. 478-491. https:// doi.org./10.1083/ismej.2013.159

Palmer, A.N., and Palmer, M.V., 2009, Caves and Karst of the USA, National Speleological Society, Inc., Huntsville, AL, p. $272-285$.

Pérez-Miranda, S., Cabirol, N., George-Téllez, R., Zamudio-Rivera, L.S., and Fernández, F.J., 2007, O-CAS, a fast and universal method for siderophore detection: Journal of Microbiological Methods, v. 70, p. 127-131. http://dx.doi.org/10.1016/j.mimet.2007.03.023

Pryor, B.M., and Maier, R.M., 2014, Making a living while starving in the dark: metagenomic insights into the energy dynamics of a carbonate cave, The ISME Journal, v. 8, p. 78-491. https://doi.org/10.1038/ismej.2013.159

Purushotham, N., Jones, E., Monk, J., and Ridgway, H., 2018, Community structure of endophytic Actinobacteria in a New Zealand native medicinal plant Pseudowintera colorata (Horopito) and their influence on plant growth: Microbial Ecology, v. 76, p. 729-740. https://doi.org/10.1007/ s00248-018-1153-9

Qin, Y., Fu, Y., Kang, W., Li, H., Gao, H., Vitalievitch, K.S., and Liu, H., 2017, Isolation and identification of a cold-adapted bacterium and its characterization for biocontrol and plant growth-promoting activity: Ecological Engineering, v. 105, p. 362-369. https://doi.org/10.1016/j.ecoleng.2017.04.045

Saha, M., Sarkar, S., Sarkar, B., Sharma, B K., Bhattacharjee, S., and Tribedi, P., 2016, Microbial siderophores and their potential applications: A review: Environmental Science and Pollution Research, v. 23, p. 3984-3999. https://doi.org/10.1007/s11356-015-4294-0

Salwan, R., Gulati, A., and Kasana, R.C., 2010, Phylogenetic diversity of alkaline protease-producing psychrotophic bacteria from glacier and cold environments of Lahaul and Spiti, India: Journal of Basic Microbiology, v. 50, p. 150-159. https://doi.org/10.1002/jobm.200800400

Sandy, M., and Butler, A., 2009, Microbial iron acquisition: Marine and terrestrial siderophores: Chemical Reviews, v. 109, p. 4580-4595. https:// doi.org/10.1021/cr9002787

Schmidt, C.S., Lovecká, P., Mrnka, L., Vychodilová, A., Strejček, M., Fenclová, M., and Demnerová, K., 2018, Distinct communities of poplar endophytes on an unpolluted and a risk element-polluted site and their plant growth-promoting potential in vitro: Microbial Ecology, v. 75, p. 955-969. https://doi.org/10.1007/s00248-017-1103-y

Schwyn, B., and Neilands, J.B., 1987, Universal chemical assay for the detection and determination of siderophores: Analytical Biochemistry, v. 160, p. 47-56. https://doi.org/10.1016/0003-2697(87)90612-9

Sorichetti, R.J., Creed, I.F., and Trick, C.G., 2014, Evidence for iron-regulated cyanobacterial predominance in oligotrophic lakes: Freshwater Biology, v. 59, p. 679-691. https://doi.org/10.1111/fwb.12295

Spilde, M.N., Northup, D.E., Boston, P.J., Schelble, R.T., Dano, K.E., Crossey, L.J., and Dahm, C.N., 2005, Geomicrobiology of cave ferromanganese deposits: A field and laboratory investigation: Geomicrobiology Journal, v. 22, p. 99-116. https://doi.org/10.1080/01490450590945889

Sullivan, T.S., Ramkissoon, S., Garrison, V.H., Ramsubhag, A., and Thies, J.E., 2012, Siderophore production of African dust microorganisms over Trinidad and Tobago: Aeobiologia, v. 28, p. 391-401. https://doi.org/10.1007/s10453-011-9243-x

Tomczyk-Żak, K., and Zielenkiewicz, U., 2016, Microbial diversity in caves: Geomicrobiology Journal, v. 33, p. 20-38. https://doi.org/10.1080/014 90451.2014.1003341

van Houdt, R., Monchy, S., Leys, N., and Mergeay M., 2009, New mobile genetic elements in Cupriavidus metallidurans $\mathrm{CH} 34$, their possible roles and occurrence in other bacteria: Antonie van Leeuwenhoek, v. 96, p. 205-226. https://doi.org/10.1007/s10482-009-9345-4 
Velasquez, I.B., Ibisanmi, E., Maas, E.W., Boyd, P.W., Nodder, S., and Sander, S.G., 2016, Ferrioxamine siderophores detected amongst iron binding ligands produced during the remineralization of marine particles: Frontiers in Marine Science: v. 3, p. 1-14. https://doi.org/10.3389/ fmars.2016.00172

Venkadesaperumal, G., Amaresan, N., and Kumar, K., 2014, Plant growth promoting capability and genetic diversity of bacteria isolated from mud volcano and lime cave of Andaman and Nicobar Islands: Brazilian Journal of Microbiology, v. 45, p. 1271-1281. http://dx.doi.org/10.1590/ S1517-83822014000400018

Vinatier, V., Wirgot, N., Joly, M., Sancelme, M., Abrantes, M., Deguillaume, L., and Delort, A.-M., 2016, Siderophores in cloud waters and potential impact on atmospheric chemistry: Production by microorganisms isolated at the Puy de Dôme Station: Environmental Science \& Technology, v. 50, p. 9315-9323. https://doi.org/10.1021/acs.est.6b02335

Wagner, K., Krause, K., Gallegos-Monterrosa, R., Sammer, D., Kovács, Á.T., and Kothe, E., 2019, The ectomycorrhizospheric habitat of norway spruce and Tricholoma vaccinum: Promotion of plant growth and fitness by a rich microorganismic community: Frontiers in Microbiology, v. 10, p. 1-14. https://doi.org/10.3389/fmicb.2019.00307

Wang, Q., Cheng, C., He, L.-Y., Huang, Z., and Sheng, X., 2014, Chitinophaga jiangningensis sp. nov., a mineral-weathering bacterium: International Journal of Systematic and Evolutionary Microbiology, v. 64, p. 260-265. https://doi.org/10.1099/ijs.0.056721-0

Winkelmann, G., 2002, Microbial siderophore-mediated transport: Biochemical Society Transactions, v. 30, p. 691-696. https://doi.org/10.1042/ bst0300691

Yadav, A.N., Sachan, S.G., Verma, P., and Saxena, A.K., 2015, Prospecting cold deserts of north western Himalayas for microbial diversity and plant growth promoting attributes: Journal of Bioscience and Bioengineering, v. 119, p. 683-693. https://doi.org/10.1016/j.jbiosc.2014.11.006 